\title{
Backbone Cleavages and Sequential Loss of Carbon Monoxide and Ammonia from Protonated AGG: A Combined Tandem Mass Spectrometry, Isotope Labeling, and Theoretical Study
}

\author{
Benjamin J. Bythell, ${ }^{\text {a }}$ Douglas F. Barofsky, ${ }^{\text {a }}$ Francesco Pingitore, ${ }^{\text {b* }}$ \\ Michael J. Polce, ${ }^{\mathrm{b}}$ Ping Wang, ${ }^{\mathrm{b}}$ Chrys Wesdemiotis, ${ }^{\mathrm{b}}$ and Béla Paizs ${ }^{\mathrm{c}}$ \\ ${ }^{a}$ Department of Chemistry, Oregon State University, Corvallis, Oregon, USA \\ ${ }^{\mathrm{b}}$ Department of Chemistry, The University of Akron, Akron, Ohio, USA \\ ${ }^{\mathrm{c}}$ Department of Molecular Biophysics, German Cancer Research Center, Heidelberg, Germany
}

\begin{abstract}
The fragmentation characteristics of protonated alanylglycylglycine, [AGG $+\mathrm{H}]^{+}$, were investigated by tandem mass spectrometry in MALDI-TOF/TOF, ion trap, and hybrid sector instruments. $b_{2}$ is the most abundant fragment ion in MALDI-TOF/TOF, ion trap, and hybrid sector metastable ion (MI) experiments, while $y_{2}$ is slightly more abundant than $b_{2}$ in collision activated dissociation (CAD) performed in the sector instrument. The A-G amide bond is cleaved on the $\mathrm{a}_{1}-\mathrm{y}_{2}$ pathway resulting in a proton-bound dimer of GG and $\mathrm{MeCH}=\mathrm{NH}$. Depending on the fragmentation conditions employed, this dimer can then (1) be detected as $\left[A G G+\mathrm{H}-\mathrm{CO}^{+}\right.$, (2) dissociate to produce $\mathrm{y}_{2}$ ions, $[\mathrm{GG}+\mathrm{H}]^{+}$, (3) dissociate to produce $\mathrm{a}_{1}$ ions, $\left[\mathrm{MeCH}=\mathrm{NH}+\mathrm{H}^{+} \text {, or (4) rearrange to expel } \mathrm{NH}_{3} \text { forming a [AGG }+\mathrm{H}-\mathrm{CO}-\mathrm{NH}_{3}\right]^{+}$ ion. The activation method and the experimental timescale employed largely dictate which of, and to what extent, these processes occur. These effects are qualitatively rationalized with the help of quantum chemical and RRKM calculations. Two mechanisms for formation of the $\left[\mathrm{AGG}+\mathrm{H}-\mathrm{CO}-\mathrm{NH}_{3}\right]^{+}$ion were evaluated through nitrogen-15 labeling experiments and quantum chemical calculations. A mechanism involving intermolecular nucleophilic attack and association of the GG and imine fragments followed by ammonia loss was found to be more energetically favorable than expulsion of ammonia in an $\mathrm{S}_{\mathrm{N}}$ 2-type reaction. (J Am Soc Mass Spectrom 2007, 18, 1291-1303) (c) 2007 American Society for Mass Spectrometry
\end{abstract}

S oft ionization techniques such as fast-atombombardment (FAB) [1], electrospray ionization (ESI) [2], and matrix-assisted laser desorption/ ionization (MALDI) $[3,4]$ have enabled tandem mass spectrometry (MS/MS) to become the standard tool for elucidation of peptide sequence. Gas-phase protonated peptides can be isolated, activated (usually by collision(s) with an inert gas), dissociated, and detected. The resulting spectra show that protonated peptides undergo backbone cleavages, dissociations in the side chains and losses of small neutrals (water, ammonia, carbon monoxide), or an amalgamation of these [5-8]. Experimental and computational studies have been undertaken on the backbone and side-chain fragmenta-

Address reprint requests to Dr. Béla Paizs, Department of Molecular Biophysics, German Cancer Research Center, Im Neuenheimer Feld 580, Heidelberg, Germany. and Dr. Chrys Wesdemiotis, Department of Chemistry, The University of Akron, 190 E. Butchel Commons, Akron, OH, 44325-3601, USA. E-mail: wesdemiotis@uakron.edu

* Current address: Berkeley Center for Synthetic Biology, University of California, 717 Potter St., Bldg. 977 MC 3224, Berkeley, CA, 94720-3224, USA. tions [9-32] as well as neutral losses [11, 18, 19, 27-29, 31, 32].

Peptide fragment ion spectra are utilized to sequence peptides and proteins with the help of various bioinformatics tools. Candidate peptides and their theoretical MS/MS spectra are generated in silico using protein and/or DNA databases and fragmentation models. The in silico spectra are then compared with the experimental MS/MS spectrum to find the most closely matching sequences. The success of this computer-aided peptide sequencing approach is directly related to the quality of the applied fragmentation models that summarize our present understanding of gas-phase peptide chemistry [7].

The "mobile proton" fragmentation model [26, 33] takes into account the energetics and reactivity of the various protonation sites of peptides. Upon excitation, the extra proton is transferred from a usually unreactive site of higher gas-phase basicity (arginine, R, or lysine, $\mathrm{K}$, side chain or the $\mathrm{N}$-terminal amino group) to form an energetically less favored but reactive, backboneamide-protonated species. Protonation of the amide 
nitrogen leads to considerable weakening of the amide bond [34], and a species such as this plays a critical role in most of the peptide fragmentation pathways (PFPs) that lead to sequence-informative $b, a$, and y ions [7]. The mobile proton model enables prediction of whether a particular peptide in a particular state of protonation is likely to produce a sequence-informative MS/MS spectrum. For example, peptide ions whose number of added protons exceeds the number of $R$ and $K$ residues are expected to fragment at the various amide bonds forming $b, a$, and $y$ ions. On the other hand, substantially less sequence coverage is expected if the number of added protons is equal to the number of $\mathrm{R}$ residues, especially if the peptide contains aspartic acid, D, and/or glutamic acid, E, and the MS/MS spectrum is dominated by cleavages C-terminal to these residues (aspartic acid effect) [7].

The recently introduced pathways in competition (PIC) fragmentation model [7], which provides a more general framework, takes into account specific features of individual peptide fragmentation pathways (PFPs) and their interaction. Fragment ion abundances in the MS/MS spectra of peptides are determined by precleavage, bond-cleavage, and postcleavage events. The precleavage phase involves the proton transfers (mobile proton) and internal rotations necessary to populate fragmenting species; hence, PIC is a logical extension to the mobile proton model. The energetics and kinetics of the competing PFPs determine which chemical bonds are cleaved upon excitation and, therefore, what kind of fragments appear as charged or neutral species in the mass spectrometer. Since MS only detects charged species, the fate of the added proton is critical, as this defines which fragments are detectable. Simple freeenergy relationships [35] can often be used to explain and/or predict relative fragment ion abundances based on fragment proton affinities (or gas-phase basicities) $[7,36]$. Furthermore, the postcleavage phase of peptide fragmentation can feature rather rich chemistry including PFPs that lead to scrambling of primary sequence information [37] and rearrangements via fragment reassociation in postcleavage proton-bound dimers [38]. While the mobile proton model does not consider the cleavage or postcleavage phases of peptide fragmentation, the flexibility of PIC enables detailed understanding of the whole fragmentation process.

The present article has two major goals. First, recent experimental and modeling studies have mainly concentrated on low-energy fragmentation processes of protonated peptides. The emerging MALDI-TOF/TOF technique features ions energized both by the MALDI process and by $1 \mathrm{keV}$ (laboratory frame) collision(s), thus, potentially opening up fragmentation channels that are frozen in the usual ion trap (IT) or quadrupoleTOF instruments. In the present paper, MS/MS fragmentation characteristics of protonated AGG in MALDI-TOF/TOF, IT, and sector instruments are presented, and the effects of various internal energy distributions and time-scales on fragment ion abundances are compared. Second, the results of using nitrogen-15 (15-N) labeling and DFT calculations to investigate the kinetics and mechanism of sequential loss of $\mathrm{CO}$ and ammonia from protonated AGG are presented and discussed. Specifically, evidence has been found for the loss of $\mathrm{CO}$ occurring on the $\mathrm{a}_{1}-\mathrm{y}_{2}$ PFP and for the reassociation of the proton-bound dimer (PBD) of GG and $\mathrm{Me}-\mathrm{CH}=\mathrm{NH}$ to form a species that can easily expel ammonia. While a similar reaction mechanism was proposed to account for combined loss of $\mathrm{CO}$ and ammonia from protonated glycinamide [39] and from $\mathrm{b}_{3}$ of protonated GGGG [38, see also SI1c] this work is the first direct evidence that primary peptide fragments can undergo reassociation type reactions in postcleavage proton-bound dimers.

\section{Materials and Methods}

\section{Materials}

The solvents (HPLC-grade water and acetonitrile), trifluoroacetic acid, acetic acid, sulfuric acid, monoammoniumphosphate and the AGG peptide were purchased from Sigma-Aldrich (Milwaukee, WI). The labeled tripeptide $\mathrm{A}\left({ }^{15} \mathrm{~N}\right) \mathrm{GG}$ was purchased from SynPep (Dublin, CA). All chemicals were used without further purification.

\section{Tandem Mass Spectrometry (MS/MS) Experiments}

The experiments were conducted on a Finnigan MAT LCQ ion trap (IT) instrument (San Jose, CA) with ESI [40, 41], an Applied Biosystems 4700 Proteomics Analyzer MALDI-TOF/TOF [42-44] with MALDI, and a Micromass AutoSpec-Q hybrid tandem MS with FAB ionization (Manchester, UK) [32, 45]. Samples ${ }^{\circ}$ for $^{\circ}$ the ${ }^{\circ} T^{\circ}$ experiments were prepared by dissolving AGG in acetonitrile/water/ acetic acid 30/70/0.1 (vol:vol) to form a $2 \times 10^{-5} \mathrm{~mol} \mathrm{~L}^{-1}$ solution, which was infused into the ESI source at a rate of $10 \mu \mathrm{L} \mathrm{min}{ }^{-1}$. The entrance to the sampling capillary was set at $-4 \mathrm{kV}$ and $\mathrm{N}_{2}$ served as the nebulizing and drying gas $\left(170^{\circ} \mathrm{C}\right)$. Collisionally activated dissociation (CAD) MS/MS of $[\mathrm{AGG}+\mathrm{H}]^{+}$were performed by ejecting all ions except $[\mathrm{AGG}+\mathrm{H}]^{+}$, and then exciting the latter to fragment in the presence of He buffer gas $\left(10^{-3}\right.$ torr) using a radiofrequency $(\mathrm{RF})$ field $\left(0.62 \mathrm{~V}_{p-p}\right)^{\circ}[46]^{\circ}$ under $^{\circ}$ automated gain control (AGC) to optimize the quantity of ions accumulated in each scan. The reproducibility of the relative abundances from multiple, repeated scans was circa $\pm 15 \%$. Additional scans were performed where the excitation level (collision energy) was incrementally increased. These scans began from well below the threshold of product ion formation and continued until all product ions had been observed.

In the MALDI-TOF/TOF experiments, the matrix was prepared by dissolving $\alpha$-cyano-4-hydroxycinnamic acid ( $\alpha$-CHCA) in acetonitrile/water/trifluoroacetic acid/monoammonium phosphate (6 mg/mL) 47/47/ 0.1/6 (vol:vol) solution at a concentration of $2 \mathrm{mg} / \mathrm{mL}$. 
The AGG peptide was dissolved in acetonitrile/water/ trifluoroacetic acid 50/50/0.1 (vol:vol) solution at a concentration of $100 \mu \mathrm{g} / \mathrm{mL}$. The sample solutions were then prepared by mixing the matrix/peptide solutions in a 1 to 1 ratio. $0.4 \mu \mathrm{L}$ of sample solution was applied to each spot on a 196-well target plate and allowed to air dry before introduction into the mass spectrometer. The MS/MS spectra consisted of 5000 laser shots per well, 10 replicate wells, with laser fluence constant and at a level low enough to prevent signal saturation. Air was used as the collision gas at $2.7 \times 10^{-8}$ ("no gas"), $7.3 \times$ $10^{-7}$ and $1.6 \times 10^{-6}$ mbar. The $[\mathrm{AGG}+\mathrm{H}]^{+}$ions formed in the MALDI process are accelerated to $8 \mathrm{keV}$, mass selected using timed ion selection (resolving power $=200 \mathrm{FWHM}$ ) then decelerated to $1 \mathrm{keV}$ (laboratory frame) for metastable ion (MI) decomposition or collisionally activated dissociation (CAD).

The sector MS/MS experiments were conducted on a Micromass AutoSpec- Q tandem mass spectrometer of EBEhQ geometry (E, electric sector; B, magnetic sector; h, RF-only hexapole; Q, quadrupole mass filter). Only the sector section (EBE) was used in this study. The protonated AGG was formed by fast atom bombardment (FAB) ionization, using $12 \mathrm{keV} \mathrm{Cs}^{+}$ions as bombarding particles and sulfuric acid as the matrix. A few $\mu \mathrm{L}$ of a saturated solution of AGG in the matrix were introduced into the ion source and bombarded by $\mathrm{Cs}^{+}$. The peptide $[\mathrm{AGG}+\mathrm{H}]^{+}$ions formed in this process were accelerated to $8 \mathrm{keV}$ and mass-selected by the EB sectors for measurement of their MI and CAD tandem mass spectra at high kinetic energy in the field-free region (FFR) between $\mathrm{EB}$ and the subsequent electric sector. The product ions from these reactions were mass-analyzed by scanning the second electric sector. In CAD mode, one of the collision cells situated in the FFR was pressurized with argon to effect $80 \%$ transmittance of the $[\mathrm{AGG}+\mathrm{H}]^{+}$beam. In $\mathrm{MS}^{3}$ experiments, a specific fragment ion from metastable $[\mathrm{M}+\mathrm{H}]^{+}$ions dissociating in the field-free region in front of the first electric sector was transmitted through EB by proper adjustment of the E and B fields, and the corresponding high-energy CAD spectrum was acquired using the above mentioned collision cell. For the fragments in the MI spectra of $[\mathrm{AGG}+\mathrm{H}]^{+}$measured at high kinetic energy, the accompanying kinetic energy releases were calculated using fragment peak widths at half height $\left(\mathrm{T}_{0.5}\right)$; the quoted $\mathrm{T}_{0.5}$ values were corrected for the main beam width using established procedures. Approximately 100 to 200 scans were summed per MI, CAD, or $\mathrm{MS}^{3}$ experiment, depending on the intensity of the main beam. The reproducibility of relative abundances was better than $\pm 15 \%$.

\section{Computational Methods}

A conformational search engine devised specifically to deal with protonated peptides was used to scan the potential energy surface (PES) of protonated alanylglycylglycine, ${ }^{\circ}\left[\mathrm{AGG}^{\circ}+{ }^{\circ} \mathrm{H}\right]^{+}\left[22,{ }^{\circ} 23,{ }^{\circ} 28^{\circ}-30\right] .{ }^{\circ}$ These ${ }^{\circ}$ calcula- tions began with molecular dynamics simulations on various forms of $[\mathrm{AGG}+\mathrm{H}]^{+}$using the InsightII program (Biosym Technologies, San Diego, CA) in conjunction with the AMBER force field modified by Paizs $^{\circ}$ et $^{\circ}$ al. ${ }^{\circ}\left[22,{ }^{\circ} 23,{ }^{\circ} 28-30\right]^{\circ}$ to $^{\circ}$ manage ${ }^{\circ}$ amide ${ }^{\circ}$ nitrogen and oxygen protonated species. During the molecular dynamics simulations, structures were regularly saved for further refinement by full geometry-optimization using the same force fields. In the next stage of the process, these structures were analyzed by a conformerfamily ${ }^{\circ}$ search $^{\circ} \operatorname{program}^{\circ}\left[22,{ }^{\circ} 23,{ }^{\circ} 28^{\circ}-30\right] .{ }^{\circ}$ This $^{\circ}$ program $^{\circ}$ is able to group optimized structures into families based on similarity of the most important characteristic torsion angles. The most stable species in these families were then fully optimized (in Heidelberg and Corvallis) at the HF/3-21G, B3LYP/6-31G(d) and the B3LYP/6-31 $+\mathrm{G}(\mathrm{d}, \mathrm{p})$ levels.

Having scanned the PES, transition structures (TSs) corresponding to various fragmentation pathways of $[\mathrm{AGG}+\mathrm{H}]^{+}$and reactions of the proton-bound dimers of $\mathrm{MeCH}=\mathrm{NH}$ and GG formed on the $\mathrm{a}_{1}-\mathrm{y}_{2}$ pathway were then sought. These were calculated at the B3LYP/ 6-31G(d) and B3LYP/6-31 + G(d,p) levels of theory. In most of the cases, the resulting transition structures were checked using intrinsic reaction coordinate (IRC) calculations to unambiguously define which minima are connected by the TS investigated. Postreaction complexes and proton-bound dimers were fully optimized at the B3LYP/6-31G(d) and B3LYP/6-31 + G(d,p) levels of theory in a manner similar to that used for the various AGG protonation sites and transition structures. Relative energies were calculated by using the B3LYP/6-31 + G(d,p) total energies and zero-point energy corrections (ZPE) determined at the B3LYP/6$31 \mathrm{G}(\mathrm{d})^{\circ}$ level $^{\circ}{ }^{\circ} \mathrm{The}^{\circ} \mathrm{Gaussian}^{\circ}[47]^{\circ}$ program $^{\circ}$ was $^{\circ}$ used $^{\circ}$ for all $a b$ initio calculations.

The unimolecular rate coefficients for transitions involving the $a_{1}-y_{2}$, water-loss, and $b_{2}-y_{1}$ TSs were calculated using the results of the DFT calculations (relative energies, vibrational frequencies, rotational constants $)^{\circ}$ via $^{\circ}$ the ${ }^{\circ} \mathrm{RRKM}^{\circ} \operatorname{method}^{\circ}[48]^{\circ}$ over $^{\circ} \mathrm{a}^{\circ}$ grid $^{\circ}$ of energies up to a limit well exceeding the calculated threshold energy of the lowest-energy fragmentation. The sum and density of states were calculated using the Beyer-Swinehart ${ }^{\circ} \operatorname{direct}^{\circ} \operatorname{count}^{\circ}$ algorithm ${ }^{\circ}$ [48].

\section{Results and Discussion}

\section{Tandem Mass Spectra (MS/MS) of Protonated AGG}

MALDI-TOF/TOF experiments yielded fragment ions similar to those observed in the ESI IT and sector experiments, but with large differences in fragment ion abundance $^{\circ}\left(\right.$ Table $\left.^{\circ} 1\right) .^{\circ}$ Fragmentation $^{\circ}$ under $^{\circ}$ MALDITOF/TOF conditions was insensitive to pressure changes in the CAD cell over two orders of magnitude. This indicates that MI dissociation played a large part in the fragmentation of the $[\mathrm{AGG}+\mathrm{H}]^{+}$ion. The base 
Table 1. Relative abundance in $\%$ of base peak intensity, using peak areas of [AGG $+\mathrm{H}]^{+}$fragment ions

\begin{tabular}{lcccrrr}
\hline \multicolumn{1}{c}{ Instrument } & \multicolumn{1}{c}{ CO } & $\mathrm{NH}_{3}$ loss & $\mathrm{y}_{2}$ & $\mathrm{~b}_{2}$ \\
\hline \hline ESI ion trap & $\mathrm{H}_{2} \mathrm{O}$ loss & CO loss & 0 & 10 & 4 & 100 \\
MALDI-TOF/TOF & 3 & 7 & 23 & 35 & 100 \\
MI FAB AutoSpec-O & $<1$ & 17 & 0 & 11 & 100 \\
CAD FAB AutoSpec-O & 5 & 9 & 28 & 100 & 0 \\
\hline
\end{tabular}

peak belongs to the $b_{2}$ ion by a significant margin in all experiments except the sector CAD where the $\mathrm{y}_{2}$ ion was slightly more abundant than the $b_{2}$. All spectra show a $\mathrm{y}_{2}$ ion peak, the relative abundance of which varies from $4 \%$ to $100 \%$ depending on the experimental

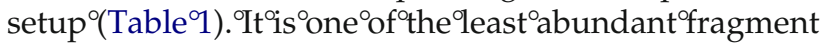
ions in the IT, whereas it is the most abundant fragment in the sector CAD. Furthermore, the relative abundance of the $\mathrm{y}_{2}$ ion exhibited in the MI sector spectra was lower than in the MALDI-TOF/TOF spectra. The intensity of the $\mathrm{H}_{2} \mathrm{O}$ loss channel is low in all experiments except those performed by MALDI-TOF/TOF, where the related peak is nearly totally missing. This channel has the largest relative abundance in the sector CAD spectra. The $\mathrm{a}_{2}$ ion was observed in the sector CAD spectra at medium and in the IT at low abundance. It should be noted that the sum of the $b_{2}$ and $a_{2}$ ion intensities $\left(\mathrm{a}_{2^{\circ}}\right.$ is $^{\circ}$ formed ${ }^{\circ}$ from $\mathrm{b}_{2^{\circ}}\left[7,011,{ }^{\circ} 12,49\right]$ by ${ }^{\circ}$ losing $\mathrm{CO}$ ) exceeds the intensity of the $\mathrm{y}_{2}$ (formal base peak) in the sector CAD spectrum.

Loss of $\mathrm{CO},\left[\mathrm{AGG}+\mathrm{H}-\mathrm{CO}^{+}\right.$is observed in all instruments except the IT. Additionally, a fragment ion peak at $m / z 159$ is observed in the IT, MALDI-TOF/ TOF, and sector CAD spectra, but not in the MI sector spectrum. For protonated AGG, this peak can be assigned as $\mathrm{x}_{2}$ or $\left[\mathrm{AGG}+\mathrm{H}-\mathrm{CO}-\mathrm{NH}_{3}\right]^{+}$. Loss of $45 \mathrm{u}$ occurs for other aliphatic peptides in the MALDI-TOF/ TOF where glycine was the second residue (see Supplemental Supporting information (Figure SI1) for GGA, GGL, GGGG, YGG spectra). However, it does not occur for aliphatic peptides where glycine was not the second amino acid (e.g., AAA, GPGG (Figure SI2)). Ordinarily, $\mathrm{x}_{\mathrm{n}}$ ions are not present in IT spectra, and no other $\mathrm{m} / \mathrm{z}$ values nominally corresponding to " $x_{n}$ ions" were observed in the MALDI-TOF/TOF (or sector CAD) spectra. The $m / z 159$ peak was also observed in $\mathrm{MS}^{3}$ experiments performed on $\left[\mathrm{AGG}+\mathrm{H}-\mathrm{CO}^{+}\right.$(Figure SI3) along with $\mathrm{y}_{2^{\circ}}$ and ${ }^{\circ} \mathrm{a}_{1^{\circ}}(\mathrm{m} / \mathrm{z} 44)^{\circ}$ ions $^{\circ}[50]^{\circ} .^{\circ}$ This $^{\circ}$ is ${ }^{\circ}$ strong evidence for the existence of the $[\mathrm{AGG}+\mathrm{H}-\mathrm{CO}-$ $\left.\mathrm{NH}_{3}\right]^{+}$ion.

$\mathrm{a}_{1}$ ions were not present in the MALDI-TOF/TOF or IT data as these instruments do not detect ion signals below $m / z 69$ or 55, respectively. However, the CAD spectrum obtained on the sector instrument does contain a small $\mathrm{a}_{1}$ fragment.

Relative appearance energies for the primary fragmentation channels were determined with the IT instrument by incrementally increasing the parent excitation level (collision energy). These scans indicated that the $b_{2}$ ion peak appears at the lowest excitation level while
$\left[\mathrm{AGG}+\mathrm{H}-\mathrm{H}_{2} \mathrm{O}\right]^{+}$and $\left[\mathrm{AGG}+\mathrm{H}-\mathrm{CO}-\mathrm{NH}_{3}\right]^{+}$ peaks appear next with the latter having much higher abundance. The $\mathrm{y}_{2}$ peak appears next followed lastly by the $a_{2}$ peak. It is worth noting here that, due to the relatively long time-scale of the IT instrument, kinetic shifts $^{\circ}$ are $^{\circ}$ small $^{\circ}[51],{ }^{\circ}$ so $^{\circ}$ the $^{\circ}$ order $^{\circ}$ of ${ }^{\circ}$ the ${ }^{\circ}$ appearance energies likely reflects the order of the true threshold energies.

\section{Fragmentation Pathways of $[A G G+H]^{+}$}

In the following sections, theoretical data are presented for the most important fragmentation channels of protonated AGG. Then the computed energetics and kinetics are used to explain the effect of the various experimental energy distributions and time-scales in the MALDI-TOF/TOF, IT, and sector instruments on the fragmentation characteristics observed.

\section{Protonation Energetics, Transition States, and Peptide Fragmentation Pathways of $\left[A G G+\mathrm{H}^{+}\right.$}

The protonation energetics of AGG along with the energetics of the $a_{1}-y_{2}, b_{2}-y_{1}$, and water-loss TSs are shown ${ }^{\circ}$ in $^{\circ} \mathrm{Table}^{\circ} 2 .^{\circ} \mathrm{As}^{\circ}$ has $^{\circ}$ been $^{\circ}$ previously $^{\circ}$ shown $^{\circ}$ for $\mathrm{GGG}^{\circ}[52],{ }^{\circ}$ the ${ }^{\circ}$ energetically $^{\circ}$ most $^{\circ}$ favored $^{\circ}$ protonation site $^{\circ}\left(\right.$ Figure $^{\circ} 1 \mathrm{a}^{\circ}{ }^{\circ}$ of $^{\circ} \mathrm{AGG}^{\circ}$ is ${ }^{\circ}$ the ${ }^{\circ} \mathrm{AG}^{\circ}$ amide $^{\circ}$ oxygen. ${ }^{\circ}$ The relative energy of the $\mathrm{N}$-terminal amino protonated species is $2.2 \mathrm{kcal} / \mathrm{mol}$ while protonation at the amide nitrogens requires at least 18 to $19 \mathrm{kcal} / \mathrm{mol}$ internal energy, ${ }^{\circ}$ which ${ }^{\circ}$ is $^{\circ}$ consistent $^{\circ}$ with $^{\circ}$ the ${ }^{\circ}$ literature ${ }^{\circ}$ [7].

\section{The $b_{2}-y_{1}$ Pathway}

Cleavage of the C-terminal amide bond of [AGG + $\mathrm{H}^{+}$on the $b_{2}-y_{1}$ pathway (Scheme 1 ) results in $a b_{2}$ ion $^{\circ}$ with $^{\circ}$ an $^{\circ}$ oxazolone $^{\circ}$ structure $^{\circ}\left[11,{ }^{\circ} 12,{ }^{\circ} 29,{ }^{\circ} 53,{ }^{\circ} 54\right]$. The first step on the $b_{2}-y_{1}$ PFP is mobilization of the added proton to the nitrogen of the C-terminal (GG) amide bond $\left(18.9 \mathrm{kcal} / \mathrm{mol}\right.$ relative energy $\left(\mathrm{E}_{\mathrm{rel}}\right)$, Table $\left.^{\circ} 2\right) .{ }^{\circ}$ Cleavage $^{\circ}$ of ${ }^{\circ}$ the ${ }^{\circ}$ protonated $^{\circ} \mathrm{C}$-terminal amide bond and simultaneous formation of the oxazolone ring take place through $\mathbf{T S} \mathbf{b}_{\mathbf{2}} \mathbf{y}_{\mathbf{1}}$ shown in $^{\circ}$ Figure ${ }^{\circ} b^{\circ}\left(\mathrm{E}_{\text {rel }}\right.$ at $29.4 \mathrm{kcal} / \mathrm{mol}$, activation entropy at $-1.0 \mathrm{cal} / \mathrm{mol} \mathrm{K}$ ). After leaving $\mathbf{T S} \_\mathbf{b}_{2} \_\mathbf{y}_{\mathbf{1}}$ various proton-bound dimers of $A_{\text {oxa }}$ and $G$ are formed. As the PA of the oxazolone structure $(217.9 \mathrm{kcal} / \mathrm{mol}$, calculated at the B3LYP/6-31 + G(d,p) level) is higher ${ }^{\circ} \operatorname{than}^{\circ}$ that $^{\circ}$ of $^{\circ} \mathrm{G}^{\circ}\left(211.4^{\circ} \mathrm{kcal} / \mathrm{mol}^{\circ}\left[55,{ }^{\circ} 56\right]\right.$, ${ }^{\circ}$ forma- 
Table 2. Relative $\left(\mathrm{kcal} \mathrm{mol}^{-1}\right)$ and total (Hartree) energies of various protonated forms of $[A G G+H]^{+}$and the $b_{2}-y_{1}, a_{1}-y_{2}$ and water loss TSs

\begin{tabular}{|c|c|c|c|c|c|c|c|c|}
\hline Species & $E_{\text {tot }}$ & $\mathrm{E}_{\mathrm{rel}}$ & Species & $E_{\text {tot }}$ & $\mathrm{E}_{\mathrm{rel}}$ & $\Delta \mathrm{H}_{298}$ & $\Delta G_{298}$ & $\Delta \mathrm{S}_{298}$ \\
\hline $\mathrm{AG}$ amide $\mathrm{O}$ protonated & -740.209780 & 0 & $\begin{array}{l}\text { AG amide } \mathrm{O} \\
\text { protonated }\end{array}$ & -740.209780 & 0 & 0 & 0 & 0 \\
\hline GG amide $\mathrm{O}$ protonated & -740.198967 & 7.2 & $\mathrm{TS} \_\mathrm{b}_{2}-\mathrm{y}_{1}$ & -740.162341 & 29.4 & 29.4 & 29.7 & -1.0 \\
\hline $\mathrm{N}$-term. Amino protonated & -740.209444 & 2.2 & TS_H $\mathrm{H}_{2} \mathrm{O} \_$loss & -740.154810 & 33.2 & 33.0 & 34.8 & -6.0 \\
\hline AG amide $\mathrm{N}$ protonated & -740.181374 & 17.8 & $T S_{-} a_{1}-Y_{2}$ & -740.144462 & 38.5 & 39.7 & 36.4 & 11.0 \\
\hline $\mathrm{GG}$ amide $\mathrm{N}$ protonated & -740.179625 & 18.9 & $\mathrm{RC} \_\mathrm{H}_{2} \mathrm{O} \_$loss & -740.187797 & $13.6 \#$ & & & \\
\hline
\end{tabular}

Total energies, $E_{\text {tot }}$ are reported at the $B 3 L Y P / 6-31 G+(d, p)$ theoretical level.

The relative energies, $E_{\text {rel }}$ (corrected for zero-point energy calculated from B3LYP/6-31G(d) vibrational frequencies) were determined with respect to the global minimum on the PES of $\left[A G G+\mathrm{H}^{+}\right.$.

Relative enthalpies $\left(\Delta \mathrm{H}_{298}\right)$ and Gibbs free energies $\left(\Delta \mathrm{G}_{298}\right)$ at $298 \mathrm{~K}$ are in $\mathrm{kcal} / \mathrm{mol}$, relative entropies $\left(\Delta \mathrm{S}_{298}\right)$ are in cal/mol $\mathrm{K}$.

\#Zero-point energy calculated using B3LYP/6-31G $+(d, p)$.

tion of $b_{2}$ is clearly favored. In agreement with this prediction, no $\mathrm{y}_{1}$ ions were experimentally observed from [AGG $+\mathrm{H}]^{+}$under any of the fragmentation conditions employed in this study.

\section{Loss of Water from Protonated AGG}


an amide $\mathrm{O}$ protonated species ( $\mathbf{R C} \_\mathbf{H}_{2} \mathbf{O} \_$loss, ${ }^{\circ}$ Figure $1 \mathrm{l}$, Scheme 2). This reactive configuration ( $\mathrm{RC}$ ) can be formed from the global minimum by rotations around the $\mathrm{N}-\mathrm{C}_{\alpha}(2)-\mathrm{CO}-\mathrm{N}^{\circ}$ and ${ }^{\circ} \mathrm{C}_{\alpha}(2)-\mathrm{CO}-\mathrm{N}-\mathrm{C}_{\alpha}(3) \mathrm{C}^{\circ}$ torsions ${ }^{\circ}$ (Figure 1c) ${ }^{\circ}$ without ${ }^{\circ}$ mobilization ${ }^{\circ}$ of ${ }^{\circ}$ the ${ }^{\circ}$ extra $^{\circ}$ proton..$^{\circ}$ Once $\mathbf{R C} \_\mathbf{H}_{2} \mathbf{O} \_$loss is populated, transfer of the extra proton to the C-terminal $\mathrm{OH}$ and nucleophilic attack of the GG amide oxygen on the $\mathrm{COOH}$ carbonyl are required to reach TS_H $\mathbf{H}_{2} \mathrm{O} \_$loss $\left(\right.$Figure $^{\circ} 1 \mathrm{~d},{ }^{\circ}$ Scheme ${ }^{\circ}$ 2). ${ }^{\circ}$ While ${ }^{\circ}$ the relative energy of this "tight" TS is relatively low at 33.2 $\mathrm{kcal} / \mathrm{mol}$, the corresponding transition is entropically disfavored (activation entropy at $-6.0 \mathrm{cal} / \mathrm{mol} \mathrm{K}$ ) due to the drastic structural changes needed to reach $\mathbf{R C} \_\mathrm{H}_{2} \mathrm{O} \_$loss and $\mathbf{T S} \_\mathrm{H}_{2} \mathrm{O} \_$loss from the global minimum. It should be mentioned that $\mathbf{R C}_{-} \mathbf{H}_{\mathbf{2}} \mathbf{O}_{-}$loss is not a local minimum on the B3LYP/6-31g(d) surface and could be optimized only at B3LYP/6-31 $+g(d, p)$. Therefore, the ZPE of this species was calculated at the latter level in contrast to other structures for which ZPEs derived at B3LYP/6-31g(d) were used. To validate the adjustment introduced by this approach we computed the ZPEs of the global minimum at the two model chemistries. These calculations indicate a ZPE decrease of $0.71 \mathrm{kcal} / \mathrm{mol}$ $(<0.5 \%)$ which fully supports the use of the B3LYP/6-31 $+\mathrm{g}(\mathrm{d}, \mathrm{p})$ value for $\mathbf{R} \mathrm{C}_{-} \mathbf{H}_{2} \mathbf{O} \_$loss.

\section{The $a_{1}-y_{2}$ PFP}

The $\mathrm{a}_{1}-\mathrm{y}_{2}$ pathway (Scheme 3a) is initiated by mobilization of the extra proton to the AG amide nitrogen $\left(\mathrm{E}_{\text {rel }}\right.$ at $\left.{ }^{\circ} 17.8^{\circ} \mathrm{kcal} / \mathrm{mol}^{\circ},{ }^{\circ} \mathrm{Table}^{\circ} 2\right){ }^{\circ}{ }^{\circ} \mathrm{This}^{\circ}$ weakens ${ }^{\circ}$ the ${ }^{\circ} \mathrm{CO}-\mathrm{NH}$ and $\left(\mathrm{H}_{2} \mathrm{NMe}\right) \mathrm{CH}-\mathrm{CO}$ bonds, which allows $\mathrm{CO}$ to be expelled and a proton-bound dimer of $\mathrm{MeCH}=\mathrm{NH}$ and GG to be formed. TS $\mathbf{a}_{1}-\mathbf{y}_{2},{ }^{\circ}$ (Figure ${ }^{\circ} 1 \mathrm{e}^{\circ}{ }^{\circ} \mathrm{E}_{\text {rel }}$ at 38.5 $\mathrm{kcal} / \mathrm{mol}$ ) is energetically the least favored of the investigated ${ }^{\circ}$ Ts, , but, ${ }^{\circ}$ thas $^{\alpha}{ }^{\circ}$ loose $^{\circ}$ character $[31],{ }^{\circ}$ so ${ }^{\circ}$ entropic factors (activation entropy at $11.0 \mathrm{cal} / \mathrm{mol} \mathrm{K}$ ) favor it relative to the "tight" $b_{2}-y_{1}$ or water loss pathways.

\section{RRKM Calculations on the PrimaryPFP of Protonated AGG}

To $^{\circ}$ approximate ${ }^{\circ}$ the ${ }^{\circ}$ time-scale ${ }^{\circ}[57]^{\circ}$ of ${ }^{\circ}$ the ${ }^{\circ}$ primary $^{\circ}$ fragmentation channels of protonated AGG, RRKM calculations were performed using the energetics, vibrational frequencies, and rotational constants derived from the modeling. The calculated unimolecular rate constants for the $b_{2}-y_{1}$, water loss, and the $a_{1}-y_{2}$ PFPs are plotted in (Figure $\left.^{\circ} 2\right)^{\circ}{ }^{\circ}$ The ${ }^{\circ}$ threshold ${ }^{\circ}$ energy $^{\circ}$ on ${ }^{\circ}$ the ${ }^{\circ} b_{2}$ - $_{1}$ pathway $(29.4 \mathrm{kcal} / \mathrm{mol})$ is lower than that of the water loss $(33.2$ $\mathrm{kcal} / \mathrm{mol})$ or the $\mathrm{a}_{1}-\mathrm{y}_{2^{\circ}}(38.5 \mathrm{kcal} / \mathrm{mol}){ }^{9}{ }^{2}{ }^{2}{ }^{\circ}$ (Table 2$)$. This order of the threshold energies is in line with the results of IT experiments where the excitation level was scanned to evaluate relative appearance energies of the main fragments (see preceding). The RRKM calculations indicate that the $b_{2}-y_{1}$ PFP is favored at low internal energies while the $\mathrm{a}_{1}-\mathrm{y}_{2}$ pathway becomes increasingly preferred at high internal energies.

The $^{\circ}$ RRKM $^{\circ}{ }^{\circ}$ Calculations ${ }^{\circ}\left(\text { Figure }^{\circ} 2\right)^{\circ}$ further ${ }^{\circ}$ suggest that the water loss PFP is kinetically disfavored compared to $b_{2}-y_{1}$ or $a_{1}-y_{2}$. In agreement with this prediction the relative abundance of [AGG $+\mathrm{H}-$ $\left.\mathrm{H}_{2} \mathrm{O}\right]^{+}$only exceeds $5 \%$ of the base peak in the sector $\mathrm{CAD}^{\circ}$ experiment $^{\circ}\left(\right.$ Table $\left.^{\circ} 1\right) .^{\circ}$ I $^{\circ}$ must $^{\circ}{ }^{\circ} e^{\circ}$ noted $^{\circ}$ that ${ }^{\circ}$ the RRKM calculations probably overestimate the branching ratio of the $b_{2}-y_{1}$ and water loss PFPs. Use of the global minimum and the corresponding TSs, to estimate the unimolecular rate constants in the RRKM calculations assumes that the extra proton is similarly mobile for each case and that the real time determining step is the dissociation. Likely this assumption is not fully valid since the proton mobilization pathways are much more complex for $b_{2}-y_{1}$ or $a_{1}-y_{2}$ than for the water loss PFP. Actually, the latter does not involve proton mobilization to populate the reactive configuration which is produced in a complicated one-step process from the global minimum. On the other hand, the $b_{2}-y_{1}$ or $a_{1}-y_{2}$ PFPs require numerous proton ${ }^{\circ}$ transitions ${ }^{\circ}\left[58,{ }^{\circ} 59\right] .{ }^{\circ}$ Consequently, ${ }^{\circ}$ over ${ }^{\circ}$ inter- 
(a)

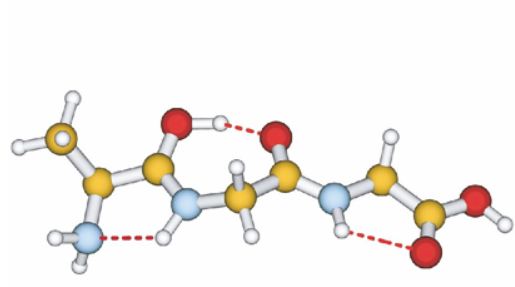

(b)

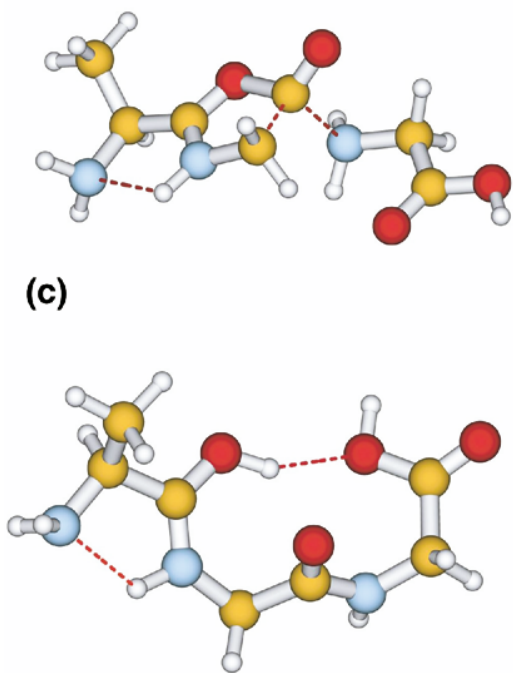

(d)

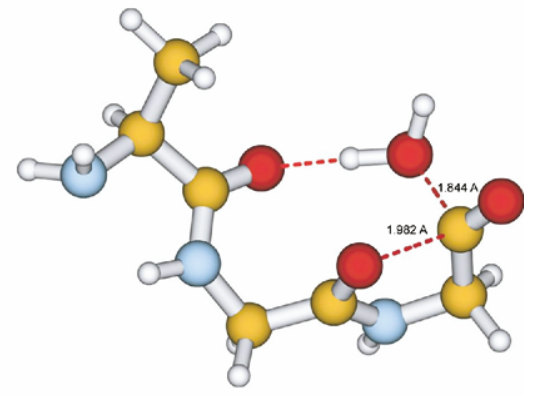

(e)

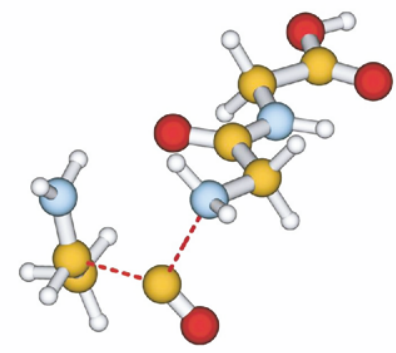

Figure 1. Selected structures on the potential energy surface of protonated AGG: (a) global minimum, (b) TS_ $\mathbf{b}_{2}-\mathbf{y}_{\mathbf{1}}$ on the $\mathrm{b}_{2}-\mathrm{y}_{1} \mathrm{PFP}$, (c) $\mathrm{RC} \_\mathbf{H}_{\mathbf{2}} \mathbf{O} \_$loss and (d) $\mathbf{T S} \_\mathbf{H}_{\mathbf{2}} \mathbf{O} \_$loss on the water loss PFP, and (e) TS $\mathbf{a}_{1}-\mathbf{y}_{2}$ on the $\mathrm{a}_{1}-\mathrm{y}_{2}$ PFP.

pretation/extrapolation of the RRKM plot should be avoided.

\section{Sequential Loss of CO and Ammonia}

from Protonated AGG: Formation

of the $\left[\mathrm{AGG}+\mathrm{H}-\mathrm{CO}-\mathrm{NH}_{3}\right]^{+}$Ion

The proton-bound dimers of $\mathrm{MeCH}=\mathrm{NH}$ and GG formed on the $a_{1}-y_{2}$ PFP can be detected as the [AGG + $\mathrm{H}-\mathrm{CO}]^{+}$peak, can dissociate to produce $\mathrm{y}_{2}$ ions, [GG $+\mathrm{H}^{+}$, or $\mathrm{a}_{1}$ ions, $\left[\mathrm{MeCH}=\mathrm{NH}+\mathrm{H}^{+}\right.$, and can rearrange and expel $\mathrm{NH}_{3}$ to form [AGG $+\mathrm{H}-\mathrm{CO}-$ $\left.\mathrm{NH}_{3}\right]^{+}$ions. Determining which of these processes occur and to what extent depends on the activation methods and the experimental timescale involved. $\mathrm{MS}^{3}$ experiments on [AGG $+\mathrm{H}-\mathrm{CO}^{+}$ion in the sector instrument (Figure SI3) show peaks with $\mathrm{m} / \mathrm{z}$ $133\left(\mathrm{y}_{2}\right), m / z 44\left(\mathrm{a}_{1}\right)$, and $m / z 159$ ([AGG $+\mathrm{H}-\mathrm{CO}-$ $\left.\mathrm{NH}_{3}\right]^{+}$).

There exist many different proton-bound dimers (PBD) of $\mathrm{MeCH}=\mathrm{NH}$ and GG with substantially different intermolecular bonding patterns. The PBD which is most energetically favored is an imine protonated species (I, Figure SI4, $\mathrm{E}_{\mathrm{rel}}$ at $11.3 \mathrm{kcal} /$ mol) despite the PA of GG, being higher than that of $\mathrm{MeCH}=\mathrm{NH}(221.9$ and $217.9 \mathrm{kcal} / \mathrm{mol}$ respectively, calculated at the B3LYP/6-31 + G(d,p) level).

Two major pathways can be envisaged for the formation of $m / z 159$ from the proton-bound dimer of $\mathrm{MeCH}=\mathrm{NH}$ and GG. On Path 1, I rearranges to form II $\left(\mathrm{E}_{\mathrm{rel}}{ }^{\circ} \mathrm{at}^{\circ} 14.1^{\circ} \mathrm{kcal} / \mathrm{mol},{ }^{\circ} \mathrm{Table}{ }^{\circ} 3{ }^{\circ}{ }^{\circ} \mathrm{Scheme}{ }^{\circ} 3 \mathrm{~b}\right.$, ${ }^{\circ}$ Figure SI4) that features a strong $\mathrm{N}^{+}-\mathrm{H} \cdot \ldots \mathrm{O}$ H-bond and a $\mathrm{C}-\mathrm{H} \cdot \cdots \mathrm{NH}_{2}$ interaction. In such a geometrical arrangement, the amino nitrogen of GG can attack the partially positively charged carbon of the imine. Formation of the new $\mathrm{N}-\mathrm{C}$ bond takes place through TS II_III $\left(E_{\text {rel }}\right.$ at $23.4 \mathrm{kcal} / \mathrm{mol}$, Scheme $3 \mathbf{b}$, Figure SI4) to form III. Proton transfers to the GG amide oxygen through TSs III_IV (E $\mathrm{E}_{\text {rel }}$ at $24.7 \mathrm{kcal} / \mathrm{mol}$, Scheme $3 b$, Figure SI4), and further to the N-terminal amino group via $\mathbf{I V}$ _V $\left(\mathrm{E}_{\text {rel }}\right.$ at $28.8 \mathrm{kcal} / \mathrm{mol}$, Scheme $3 \mathbf{b}$, Figure SI4) lead to structure $\mathbf{V}\left(\mathrm{E}_{\text {rel }}\right.$ at 14.5 $\mathrm{kcal} / \mathrm{mol}$, Scheme $3 \mathbf{b}$, Figure SI4), which can expel ammonia via TS V_VI $\left(E_{\text {rel }}\right.$ at $21.5 \mathrm{kcal} / \mathrm{mol}$, Scheme 

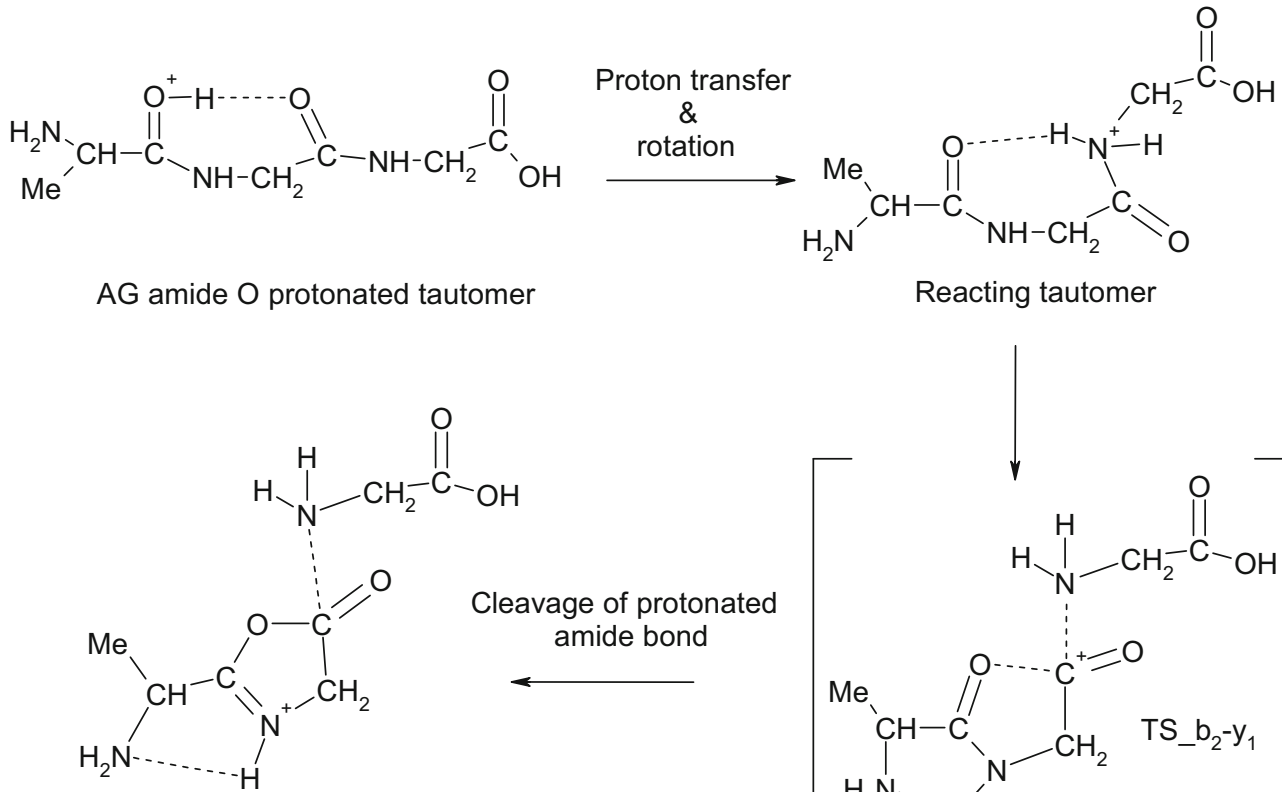

Post reaction complex
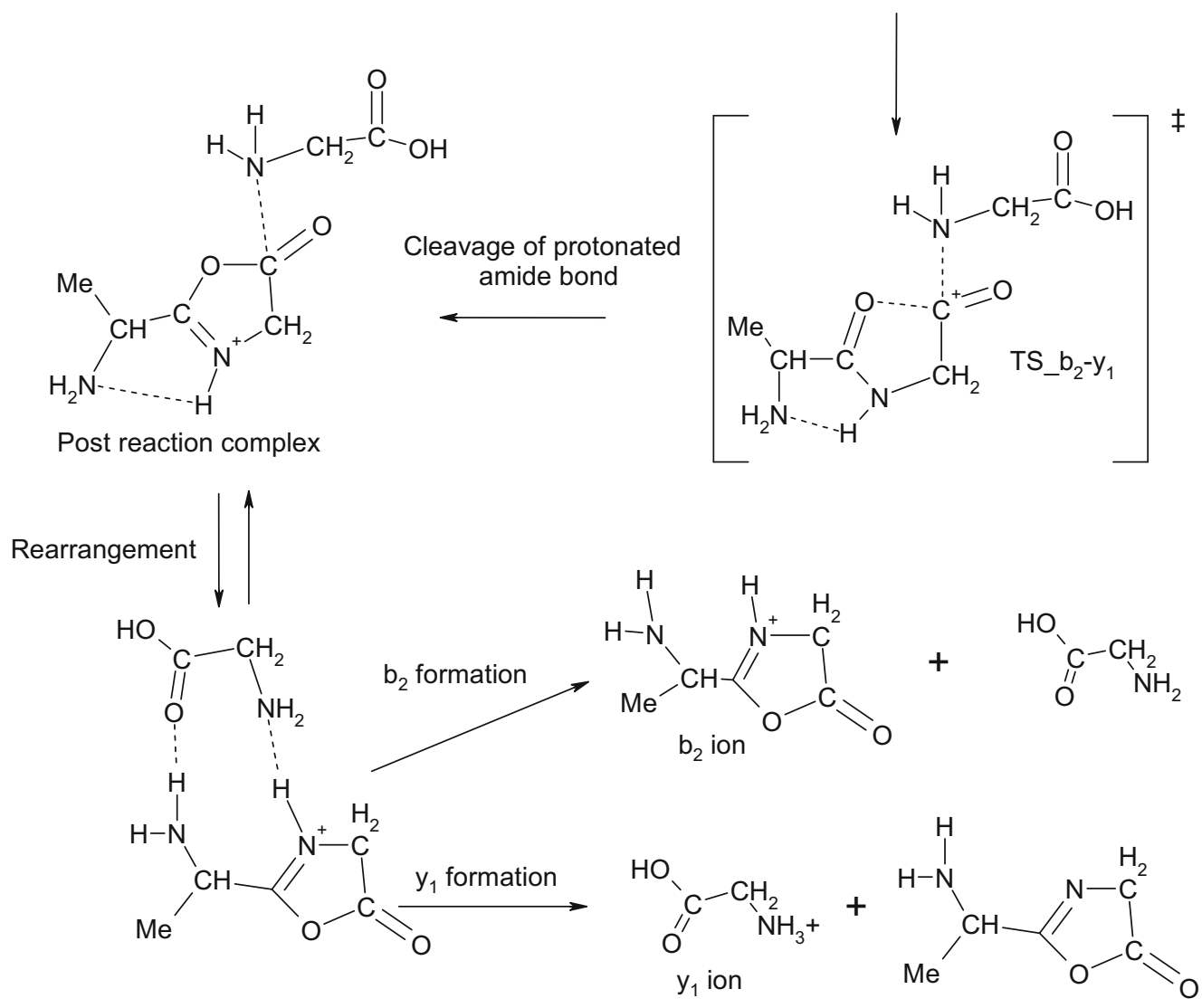

Scheme 1. The $b_{2}-y_{1}$ PFP of protonated AGG.

$3 b$, Figure SI44). Note that the highest energy structure on Path 1 is TS IV_V, at $28.8 \mathrm{kcal} / \mathrm{mol}$ relative energy, which is lower than the $\mathrm{a}_{1}-\mathrm{y}_{2}$ threshold energy at $38.5 \mathrm{kcal} / \mathrm{mol}$.

An alternative pathway (Path 2, Scheme 3b) involves rearrangement of $\mathbf{I}$ and proton transfer to GG to form VII $\left(E_{\text {rel }}\right.$ at $15.9 \mathrm{kcal} / \mathrm{mol}$, Scheme $3 \mathbf{b}$, Figure SI4). VII then rearranges to form VIII $\left(\mathrm{E}_{\mathrm{rel}}\right.$ at $26.2 \mathrm{kcal} / \mathrm{mol}$, Scheme $3 b$, Figure SI4), which can undergo an $\mathrm{S}_{\mathrm{N}} 2$-type reaction to expel ammonia in a one-step process via TS (VIII_VI (E rel $_{\text {at }} 51.5 \mathrm{kcal} / \mathrm{mol}$, Scheme 3b, Figure SI4)) to form the same final product as Path 1, namely structure VI. Path 2 requires a TS (VIII_VI) with energy considerably greater than the $\mathrm{a}_{1}-\mathrm{y}_{2}$ TS energy. Path 2 would therefore require a significantly greater input of energy to be active than Path 1 . It should be noted that while performing well for TS and reaction-path geometries, density functional methods perform less well for activation barrier height calculations for $\mathrm{S}_{\mathrm{N}} 2$ reactions $[60]^{\circ}$ and $^{\circ}$ underestimate $^{\circ}$ their $^{\circ}$ barrier $^{\circ}$ heights $^{\circ}[61] .^{\circ}$ As such, it is reasonable to expect the $\mathrm{E}_{\text {rel }}$ of TS_VIII_VI (Path 2) to be a lower bound thus making Path 1 even more likely in terms of energy. These findings are also in agreement with the 15- $\mathrm{N}$ labeling results presented in this paper (see below).

The energetics of Paths 1 and 2 are summarized in Figure $^{\circ} 3,{ }^{\circ}$ which $^{\circ}$ also $^{\circ}$ displays $^{\circ}$ the $^{\circ}$ relative $^{\circ}$ energies $^{\circ}$ of the " $\mathrm{a}_{1}+\mathrm{GG}+\mathrm{CO}^{\prime}$ and "MeCH=NH$+\mathrm{y}_{2}+\mathrm{CO}^{\prime}$ $\mathrm{a}_{1}-\mathrm{y}_{2}$ exit channels. The latter is nearly equi-energetic with the $a_{1}-y_{2}$ TS in line with the low kinetic energy release $\left(\mathrm{T}_{0.5}\right.$ at $\left.0.1 \mathrm{eV}\right)$ observed for the formation of the $\mathrm{y}_{2}$ ion in MI experiments on protonated AGG. Path 1 is clearly energetically favored over Path 2, considering formation of the $m / z 159$ ion. However, Path 1 is a multi-step process that can be kinetically controlled in experiments with short timescales.

CAD experiments on the sector instrument were also carried out with the labeled $A\left({ }^{15} \mathrm{~N}\right) \mathrm{GG}$ peptide. 


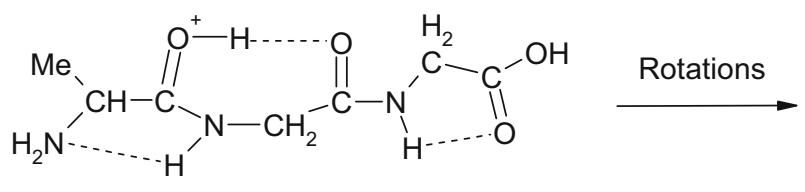

AG amide $O$ protonated tautomer<smiles>C[C@@H]1NC[C@H]2NC[C@@H]1OC(=O)NCC(=O)O2</smiles>

Reacting configuration of protonated GG amide oxygen ( $\mathrm{RC} \_\mathrm{H}_{2} \mathrm{O} \_$loss)<smiles>CC(C)OC(=O)CNC(=O)CN1CN[C@H](C)C1=O</smiles>

TS_ $\mathrm{H}_{2} \mathrm{O}$ loss

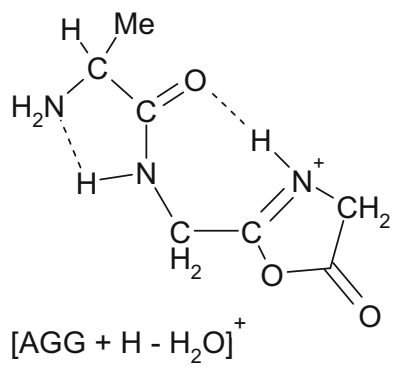

Scheme 2. The water-loss PFP of protonated AGG.

The CAD spectrum of $\left[\mathrm{A}\left({ }^{15} \mathrm{~N}\right) \mathrm{GG}+\mathrm{H}-\mathrm{CO}\right]^{+}(\mathrm{m} / \mathrm{z}$ 177) shows fragments at $m / z 159$ (-18 u, corresponding to loss of $\left.{ }^{15} \mathrm{NH}_{3}\right), 133$ (-44u, corresponding to loss of ${ }^{15} \mathrm{NH}=\mathrm{CH}-\mathrm{CH}_{3}$ ), and 45 (corresponding to ion $\left[{ }^{15} \mathrm{NH}_{2}=\mathrm{CH}-\mathrm{CH}_{3}\right]^{+}$), which provide corroborating evidence for the dominance of Path 1 over Path 2 of Scheme $\mathbf{3 b}$ in agreement with the theoretical results.

\section{Effect of Internal Energy Distribution and Fragmentation Timescale on Relative Fragment Ion Abundances}

The DFT and RRKM calculations indicate that the branching ratios of the fragment ions from the $b_{2}-y_{1}$ and $a_{1}-y_{2}$ PFPs are a reasonable measure of the parent excitation level. That is, dominance of the former indicates mild while dominance of the latter suggests harsher excitation. These abundance ratios are 102/ $14,{ }^{\circ} 100 / 65,{ }^{\circ} 100 / 28,{ }^{\circ}$ and $^{\circ} 121 / 137^{\circ}\left(\text { Table }^{\circ} 1\right)^{\circ}$ for ${ }^{\circ}$ the ${ }^{\circ} \mathrm{IT}$, MALDI-TOF/TOF, MI sector, and CAD sector instruments, respectively. As expected, the sector CAD precursor ions are the most energized. The MALDI-
TOF/TOF precursor ions appear to be more energized than those produced in the IT or MI sector experiments but less excited than those produced in the sector CAD.

This relative degree of precursor ion energization is also consistent with the final CAD products arising from the $a_{1}-y_{2}$ PFP. Here the $y_{2} /$ [AGG $+\mathrm{H}-\mathrm{CO}-$ $\left.\mathrm{NH}_{3}\right]^{+}$ion ratios are $4 / 10,35 / 23,100 / 28$ for the IT, MALDI-TOF/TOF, and sector CAD instruments, respectively ${ }^{\circ}\left(\right.$ see $^{\circ}$ Table 1 ). The increasing ${ }^{\circ}$ ratio ${ }^{\circ}$ reflects ${ }^{\circ}$ the increasing energization of the precursor ions making dissociation of the PBD to form $\mathrm{y}_{2}$ ions ${ }^{9}$ more likely $[62]$. This trend is also supported by the decreasing timescale of the experiment, which leaves less time for the $\mathrm{PBD}$ to rearrange and form $\left[\mathrm{AGG}+\mathrm{H}-\mathrm{CO}-\mathrm{NH}_{3}\right]^{+}$.

The high-energy $C A D$ experiments performed in the instrument using FAB ionization deposit a broad range of internal energies in a single collision. The precursor ion dissociates in less than a few microseconds $(\sim 2 \mu \mathrm{s})$; under these conditions, several competitive dissociations can take place simultaneously, depending on the amount of energy gained by a particular precursor ion 




Scheme 3a. (a) The $\mathrm{a}_{1}-\mathrm{y}_{2}$ PFP of protonated AGG. (b) Sequential loss of $\mathrm{CO}$ and $\mathrm{NH}_{3}$ from protonated AGG.

as $^{\circ}$ well $^{\circ}$ as $^{\circ}$ the ${ }^{\circ}$ dissociation ${ }^{\circ}$ kinetics $^{\circ}[63] . .^{\circ}$ Consequently, each of the $\mathrm{b}_{2}-\mathrm{y}_{1}, \mathrm{a}_{1}-\mathrm{y}_{2}$, and water loss PFPs are active with $^{\circ}$ medium $^{\circ}$ to $^{\circ}$ high $^{\circ}$ fragment $^{\circ}$ ion $^{\circ}$ abundances $^{\circ}($ Table 1 1).

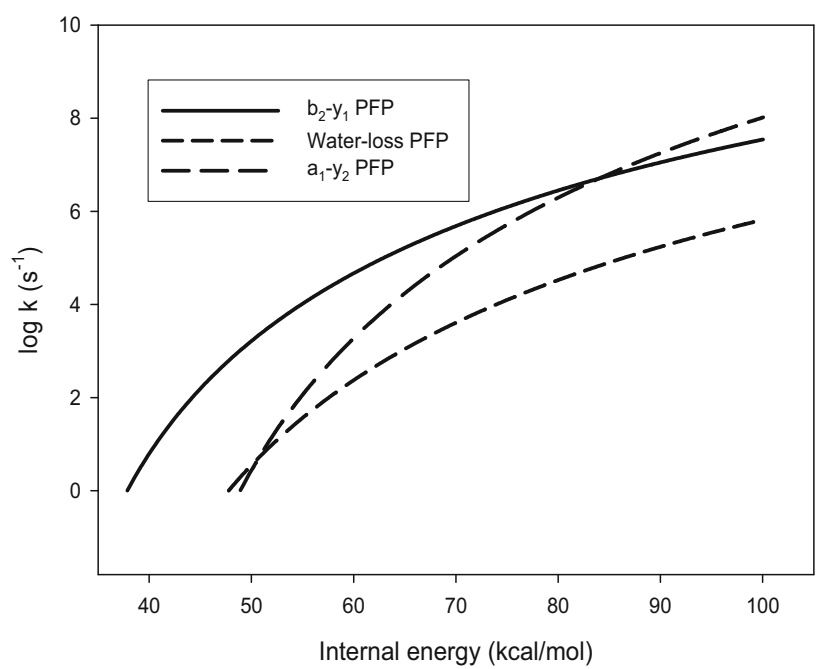

Figure 2. Unimolecular rate constants $\left(\mathrm{s}^{-1}\right)$ calculated by the RRKM formalism for the $b_{2}-y_{1}$, water-loss, and $a_{1}-y_{2}$ TSs.
This is in direct contrast to the low-energy CAD in the IT, which utilizes multiple collisions each depositing a small amount of internal energy to activate the precursor ion. This makes millisecond time windows $\left(\sim 10^{\circ} \mathrm{ms}\right)^{\circ}$ available ${ }^{\circ}{ }^{\circ}{ }^{\circ}$ dissociation $[41,942,46]$. Once the critical energy for a fast reaction is reached, the precursor ion reacts by this channel leading to an accumulation of the corresponding fragment ion. Any competing reaction is obstructed unless its critical energy and kinetics are very similar to the channel accumulating fragment ${ }^{\circ}$ ions ${ }^{\circ}[32]$. This ${ }^{\circ}$ effect ${ }^{\circ}$ is $^{\circ}{ }^{\circ}$ learly ${ }^{\circ}$ observed ${ }^{\circ}{ }^{\circ}$ the high $b_{2}-y_{1} / a_{1}-y_{2}$ abundance ratio in the IT experiment. Multiple collision conditions at low-energy may, however, promote consecutive fragmentations if the corresponding ${ }^{\circ}$ energetics ${ }^{\circ}$ are $^{\circ}$ favorable ${ }^{\circ}[27] .{ }^{\circ} \mathrm{As}^{\circ} \mathrm{a}^{\circ}$ consequence, a weak $a_{2}$ ion signal is observed due to activity of the $b_{2} \rightarrow a_{2}$ pathway. It is worth noting here that no [AGG $+\mathrm{H}-\mathrm{CO}]^{+}$ions were observed in the IT experiment. ${ }^{\circ}$ This $^{\circ}$ is $^{\circ}$ very $^{\circ}$ likely $^{\circ}$ due $^{\circ}$ to ${ }^{\circ}$ the $e^{\circ}$ millisecond time-scale of the fragmentation that allows the corresponding PBDs to rearrange and fragment by losing $\mathrm{NH}_{3}$.to form 90 \% $\mathrm{m} / \mathrm{z} 159^{\circ}(10 \%$ of the base peak, Table 1$)$. Note $^{\circ}$ that ${ }^{\circ}$ the ${ }^{\circ}$ energetics $^{\circ}$ of $^{\circ}$ Path $^{\circ} 1^{\circ}\left(\text { Figure }^{\circ} 3\right)^{\circ}$ clearly favor this multi-step transition. 


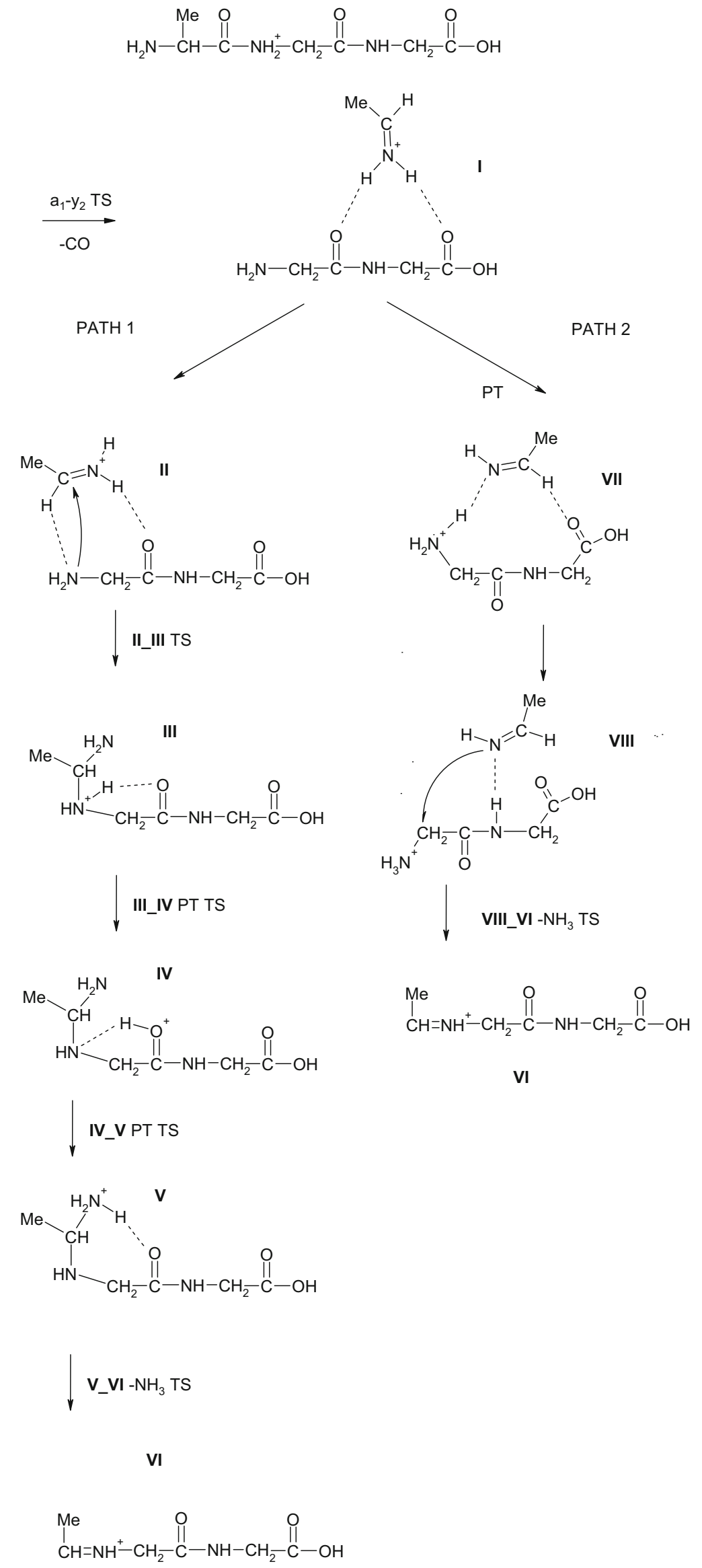


Table 3. Relative $\left(\mathrm{kcal} \mathrm{mol}^{-1}\right)$ and total (Hartree) energies of proton-bound dimers and related species shown in Scheme 3

\begin{tabular}{|c|c|c|c|c|c|}
\hline Species & $E_{\text {tot }}$ & $E_{\text {rel. }}$ & Species & $\mathrm{E}_{\text {tot }}$ & $\mathrm{E}_{\mathrm{rel}}$ \\
\hline I & -626.867503 & 11.3 & II & -626.862438 & 14.1 \\
\hline II_III & -626.849058 & 23.4 & III & -626.855829 & 20.7 \\
\hline III_IV & -626.844640 & 24.7 & IV & -626.845254 & 26.9 \\
\hline IV_V & -626.841334 & 28.8 & V & -626.865704 & 14.5 \\
\hline V_VI & -626.850038 & 21.5 & VI $\mathrm{NH}_{3}$ comp & -626.864984 & 12.3 \\
\hline VI and $\mathrm{NH}_{3}$ & -626.836471 & 27.7 & VII & -626.859314 & 15.9 \\
\hline VIII & -626.843598 & 26.2 & VIII_VI & -626.801695 & 51.5 \\
\hline
\end{tabular}

Total energies are reported at the $\mathrm{B} 3 \mathrm{LYP} / 6-31 \mathrm{G}+(\mathrm{d}, \mathrm{p})$ theoretical level.

The relative energies (corrected for zero-point energy calculated from B3LYP/6-31G(d) vibrational frequencies) were determined with respect to the global minimum on the PES of $[\mathrm{AGG}+\mathrm{H}]^{+}$, taking into account the ZPE-corrected total energy of $\mathrm{CO}\left(\mathrm{E}_{\mathrm{tot}}\right.$ at $-113.312292 \mathrm{H}, \mathrm{ZPE}$ at $0.00503 \mathrm{H}$ ) eliminated on the $\mathrm{a}_{1}-\mathrm{y}_{2}$ PFP.

The fragment ion abundances observed in the spectra produced with the MI sector are similar to the corresponding IT values including the branching ratio of the fragment ions from the $b_{2}-y_{1}$ and $a_{1}-y_{2}$ PFPs (100/28 and 102/14, respectively). There are two differences between the IT and MI sector fragment abundances: no CO loss peak is observed in the IT (see preceding for explanation) while the ion with $\mathrm{m} / \mathrm{z} 159$ is not formed in the MI sector experiment. The latter can be explained by the short $(\sim 2 \mu \mathrm{s})$ time scale of the MI experiment and the rather narrow internal energy distribution of the corresponding parent population.

The MALDI-TOF/TOF instrument lies between two extremes as internal energy is acquired by the precursor ion during the ionization processes and subsequently in the collision cell through which it passes at $1 \mathrm{keV}$.
Consequently, precursor ions in the collision cell $(\sim 6 \mu \mathrm{s}$ for $m / z 204$ ) can decay metastabily, as a result of CAD or a mixture of the two. The resulting ensemble of ions is then re-accelerated, focused, and detected. The higher internal energy imparted by the MALDI-TOF/TOF leads to increased fragmentation on the $\mathrm{a}_{1}-\mathrm{y}_{2}$ pathway relative to the IT and MI sector experiments. The MALDI-TOF/TOF timescale is still sufficiently long to enable observation of species formed from chemical reactions other than direct dissociation and their intermediate $^{\circ}\left(\right.$ see $^{\circ}$ Table $\left.^{\circ} 1\right)$. ${ }^{\circ}$ Interestingly, ${ }^{\circ}$ no $^{\circ}$ evidence $^{\circ}$ for ${ }^{\circ} \mathrm{a}$ water loss peak is observed in the MALDI-TOF/TOF spectrum, but evidence for this reaction is seen at the $3 \%$ to $15 \%$ level in the spectra from the other experiments. Ionization by MALDI is more energized than is that by ESI or FAB. As mentioned above, the water loss PFP is initiated from a structure $\left(\mathbf{R C} \_\mathbf{H}_{2} \mathbf{O} \_\right.$loss, $E_{\text {rel }}$ at

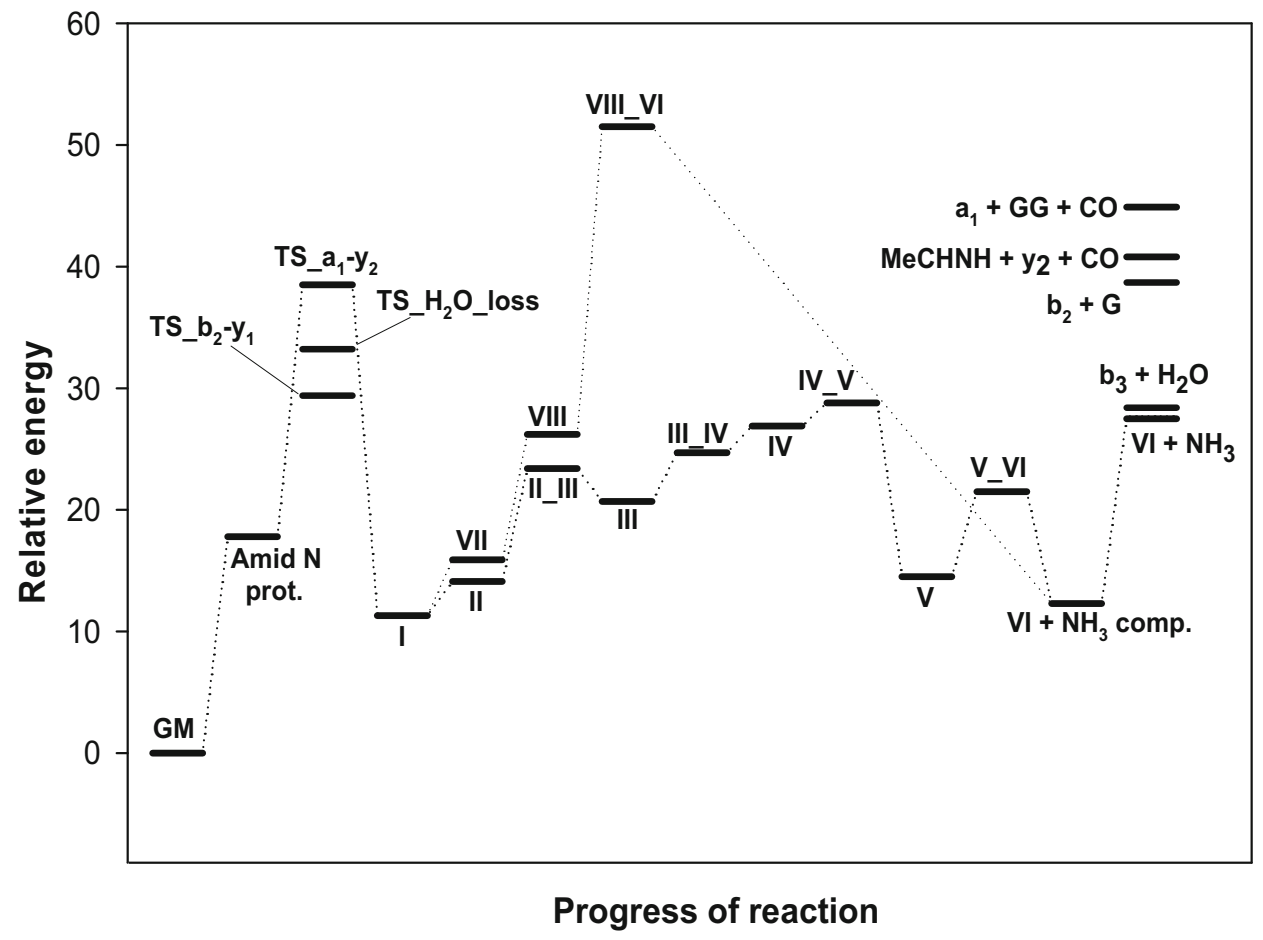

Figure 3. Relative energetics of paths 1 and 2 for [AGG $\left.+\mathrm{H}-\mathrm{CO}-\mathrm{NH}_{3}\right]^{+}$ion formation. For

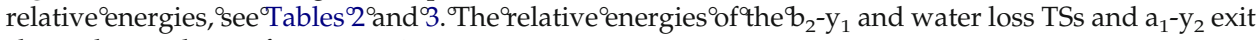
channels are shown for comparison. 


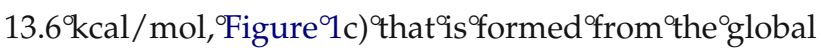
minimum by backbone rotations without transfer of the ionizing proton. It can easily happen that the highly energized MALDI-TOF/TOF precursors populate protonation states like the $\mathrm{N}$-terminal amino group at 2.2 $\mathrm{kcal} / \mathrm{mol}^{\circ}{ }^{\circ}$ lative ${ }^{\circ} \operatorname{energy}^{\circ}\left(\right.$ Table $\left.^{\circ} 2\right)$, ${ }^{\circ}$ therefore ${ }^{\circ}$ suppressing the water-loss PFP that requires protonation at the A-G amide oxygen.

\section{Conclusions}

A mixed ab initio, 15-N labeling and RRKM technique was successfully used to model fragmentation of [AGG $+\mathrm{H}]^{+}$under a variety of fragmentation conditions. The different fragmentation patterns observed in the three mass spectrometers reflected differences in internal energy distributions and timescales available for dissociation. Combined tandem MS experiments offer a powerful tool for probing the complex gas-phase chemistry of protonated peptides. Accompanying computational and labeling studies can provide important mechanistic details not readily observed from tandem mass spectra alone.

Similar reactions to the formation of [AGG $+\mathrm{H}-$ $\left.\mathrm{CO}-\mathrm{NH}_{3}\right]^{+}$peak could easily occur for other protonated peptides and consequently lead to unexpected fragment ions in MS/MS spectra. This, in turn, could lead to erroneous peptide and protein identification using current bioinformatics tools. As such, the postcleavage phase of peptide fragmentation warrants further study so that the PIC model may be improved and implemented into software to enhance the effectiveness of peptide sequencing algorithms.

\section{Acknowledgments}

The work of BJB and DFB was supported in part by the Environmental Health Sciences Center under NIEHS grant number ES00210. BP is grateful to the Deutsche Forschungsgemeinschaft (SU 244/3-1) for financial support. CW thanks the NSF for generous financial support (CHE - 0111128). BJB thanks Y. Vasilev for helpful discussions during preparation of the manuscript.

\section{References}

1. Barber, M.I.; Bordoli, R. A.; Sedgewick, R. D.; Tyler, A. N. Fast atom bombardment of solids (F.A.B.): a new ion source for mass spectrometry. J. Chem. Soc. Chem. Commun. 1981, 325-327.

2. Yamashita, M.; Fenn, J. B. Electrospray ion source: Another variation on the free-jet theme. J. Phys. Chem. 1984, 88, 4451-4459.

3. Karas, M.; Bachmann, D.; Bahr, U.; Hillenkamp, F. Matrix-assisted ultraviolet laser desorption of nonvolatile compounds. Int. J. Mass Spectrom. Ion Processes 1987, 78, 53-68.

4. Karas, M.; Hillenkamp, F. Laser desorption ionization of proteins with molecular masses exceeding 10,000 Daltons. Anal. Chem 1988, 60, 2299-2301.

5. (a) Biemann, K. Sequencing of peptides by tandem mass spectrometry and high-energy collision-induced dissociation. Methods Enzymol. 1990, 193, 455-479. (b) Biemann, K. Peptides and proteins: Overview and strategy. Methods Enzymol 1990, 193, 351-360.

6. Papayannopoulos, I. A. The interpretation of collision-induced dissociation tandem mass spectra of peptides. Mass Spectrom. Rev. 1995, 14(1), 49-73.

7. Paizs, B.; Suhai, S. Fragmentation pathways of protonated peptides. Mass Spectrom. Rev. 2005, 24, 508-548.

8. Wang, P.; Kish, M. M.; Wesdemiotis, C. Fragmentation mechanisms of peptide ions. Encycl. Mass Spectrom. 2005, 2, 139-151.
9. Ballard, K. D.; Gaskell, S. J. Dehydration of Peptide $[\mathrm{M} \mathrm{H}]^{+}$Ions in the Gass Phase. J. Am. Soc. Mass Spectrom. 1993, 4, 477-481.

10. Cordero, M. M.; Houser, J. J.; Wesdemiotis, C. The neutral products formed during backbone fragmentations of protonated peptides in tandem mass spectrometry. Anal. Chem. 1993, 65, 1594-1601.

11. Yalcin, T.; Khouw, C.; Csizmadia, I. G.; Peterson, M. R.; Harrison, A. G. Why are b ions stable species in peptide spectra? J. Am. Soc. Mass Spectrom. 1995, 6(12), 1165-1174.

12. Yalcin, T.; Csizmadia, I. G.; Peterson, M. R.; Harrison, A. G. The structure and fragmentation of $B_{n}(n>/=3)$ ions in peptide spectra. J. Am. Soc. Mass Spectrom. 1996, 7, 233-242.

13. Dongré, A. R.; Somogyi, A.; Wysocki, V. H. Surface-induced dissociation: An effective tool to probe structure, energetics and fragmentation mechanisms of protonated peptides. J. Mass Spectrom. 1996, 31(4), 339-350.

14. Ambihapathy, K.; Yalcin, T.; Leung, H.-W.; Harrison, A. G. Pathways to immonium ions in the fragmentation of protonated peptides. J. Mass Spectrom. 1997, 32, 209-215.

15. Nold, M. J.; Wesdemiotis, C.; Yalcin, T.; Harrison, A. G. Amide bond dissociation in protonated peptides. Structures of the N-terminal ionic and neutral fragments. Int. J. Mass Spectrom. Ion Processes 1997, 164 137-153.

16. Klassen, J. S.; Kebarle, P. Collision-Induced Dissociation Threshold Energies of Protonated Glycine, Glycinamide, and Some Related Small Peptides and Peptide Amino Amides. J. Am. Chem. Soc. 1997, 164, 6552-6563.

17. Reid, G. E.; Simpson, R. J.; O'Hair, R. A. J. A mass spectrometric and ab initio study of the pathways for dehydration of simple glycine and cysteine-containing peptide $[\mathrm{M}+\mathrm{H}]^{+}$ions. J. Am. Soc. Mass Spectrom 1998, 9(9), 945-956.

18. O'Hair, R. A. J.; Styles, M. L.; Reid, G. E. Role of the sulfhydryl group on the gas phase fragmentation reactions of protonated cysteine and cysteine containing peptides. J. Am. Soc. Mass Spectrom. 1998, 9(12), 1275-1284.

19. Reid, G. E.; Simpson, R. J.; O'Hair, R. A. J. Probing the fragmentation reactions of protonated glycine oligomers via multistage mass spectrometry and gas phase ion molecule hydrogen/deuterium exchange. Int. J. Mass Spectrom. Ion Processes 1999, 190/191, 209-230.

20. Nold, M. J.; Cerda, B. A.; Wesdemiotis, C. Proton affinities of the N- and C-terminal segments arising upon the dissociation of the amide bond in protonated peptides. J. Am. Soc. Mass Spectrom., 1999, 10, 1-8.

21. Tsaprailis, G.; Nair, H.; Somogyi, A.; Wysocki, V. H.; Zhong, W.; Futrell, J. H.; Summerfield, S. G.; Gaskell, S. J. Influence of Secondary Structure on the Fragmentation of Protonated Peptides. J. Am. Chem. Soc. 1999, 121, 5142-5154.

22. Paizs, B.; Lendvay, G.; Vékey, K.; Suhai, S. Formation of $\mathrm{b}_{2}{ }^{+}$ions from protonated peptides: an ab initio study. Rapid Commun. Mass Spectrom. 1999, 13, 525-533.

23. Paizs, B.; Szlavik, Z.; Lendvay, G.; Vékey, K.; Suhai, S. Formation of $a_{2}{ }^{+}$ ions of protonated peptides. An ab initio study. Rapid Commun. Mass Spectrom. 2000, 14, 746-755.

24. Harrison, A. G.; Csizmadia, I. G.; Tang, T.-H.; Tu, Y.-P. Reaction competition in the fragmentation of protonated dipeptides. J. Mass Spectrom. 2000, 35, 683-688.

25. Polce, M. J.; Ren, D.; Wesdemiotis, C. Dissociation of the peptide bond in protonated peptides. J. Mass Spectrom. 2000, 35(12), 1391-1398.

26. Wysocki, V. H.; Tsaprailis, G.; Smith, L. L.; Breci, L. A. Mobile and localized protons: a framework for understanding peptide dissociation. J. Mass Spectrom. 2000, 35, 1399-1406

27. Laskin, J.; Denisov, E.; Futrell, J. H. A Comparative Study of CollisionInduced and Surface-Induced Dissociation. 1. Fragmentation of Protonated Dialanine. I. Am. Chem. Soc. 2000, 122, 9703-9714.

28. Paizs, B.; Suhai, S. Theoretical study of the main fragmentation pathways for protonated glycylglycine. Rapid Commun. Mass Spectrom. 2001, 15, 651-663.

29. Paizs, B.; Suhai, S. Combined quantum chemical and RRKM modeling of the main fragmentation pathways of GGG. II. Formation of $b_{2}, y_{1}$ and $\mathrm{y}_{2}$ ions. Rapid Commun. Mass Spectrom 2002, 16, 375-389.

30. Paizs, B.; Suhai, S.; Harrison, A. G. Experimental and theoretical investigation of the main fragmentation pathways of protonated H-GlyGly-Sar-OH and H-Gly-Sar-Sar-OH. J. Am. Soc. Mass Spectrom. 2003, 14 , 1454-1469.

31. Balta, B.; Aviyente, V.; Lifshitz, C. Elimination of Water from the Carboxyl Group of GlyGlyH+ ${ }^{+}$. J. Am. Soc. Mass Spectrom. 2003, 14 1192-1203.

32. Pingitore, F.; Polce, M. J.; Wang, P.; Wesdemiotis, C.; Paizs, B. Intramolecular condensation reactions in protonated dipeptides: Carbon monoxide, water, and ammonia losses in competition. J. Am. Soc. Mass Spectrom. 2004, 15(7), 1025-1038.

33. Dongre, A. R.; Jones, J. L.; Somogyi, A.; Wysocki, V. H. Influence of Peptide Composition, Gas-Phase Basicity, and Chemical Modification on Fragmentation Efficiency: Evidence for the Mobile Proton Model. J. Am. Chem. Soc. 1996, 118, 8365-8374.

34. Somogyi, A.; Wysocki, V. H.; Mayer, I. The Effect of Protonation Site on Bond Strengths in Simple Peptides: Application of ab Initio and MNDO Bond Orders and MNDO Energy Partitioning. J. Am. Soc. Mass Spectrom. 1994, 5, 704-717.

35. Harrison, A. G. Linear free energy correlations in mass spectrometry. J. Mass Spectrom. 1999, 34, 577-589. 
36. Paizs, B.; Suhai, S. Towards understanding some ion intensity relationships for the tandem mass spectra of protonated peptides. Rapid Commun. Mass Spectrom. 2002, 16, 1699-1702.

37. Harrison, A. G.; Young, A. B.; Bleiholder, B.; Suhai, S.; Paizs, B. Scrambling of Sequence Information in Collision-Induced Dissociation of Peptides. J. Am. Chem. Soc. 2006, 128, 10364-10365.

38. Cooper, T.; Talaty, E.; Grove, J.; Suhai, S.; Paizs, B.; Van Stipdonk, M. Isotope Labeling and Theoretical Study of the Formation of $\mathrm{a}_{3}{ }^{*}$ Ions from Protonated Tetraglycine. J. Am. Soc. Mass Spectrom. 2006, 17, 1654-1664.

39. Kinser, R. D.; Ridge, D. P.; Hvistendahl, G.; Rasmussen, B.; Uggerud, E. The unimolecular chemistry of protonated glycinamide and the proton affinity of glycinamide mass spectrometric experiments and theoretical model. Chem. Eur. J. 1996, 2, 1143-1149.

40. March, R. E. An Introduction to Quadrupole Ion Trap Mass Spectrometry. J. Mass Spectrom. 1997, 32, 351-369.

41. March, R. E. Quadrupole Ion Trap Mass Spectrometry: Theory, Simulations, Recent Developments and Applications. Rapid Commun. Mass Spectrom. 1998, 12, 1543-1554.

42. Medzihradszky, K. F.; Campbell, J. M.; Baldwin, M. A.; Falick, A. M.; Juhasz, P.; Vestal, M. L.; Burlingame, A. L. The Characteristics of Peptide Collision-Induced Dissociation Using a High-Performance MALDI-TOF/TOF Tandem Mass Spectrometer. Anal. Chem. 2000, 72(3), $552-558$.

43. Juhasz, P.; Campbell, J. M.; Vestal, M. L. MALDI-TOF/TOF technology for peptide sequencing and protein identification. In Mass Spectrometry and Hyphenated Techniques in Neuropeptide Research; Silberring, J., Ekman, R., eds. 2002, 375-413.

44. Bienvenut, W. V.; Deon, C.; Pasquarello, C.; Campbell, J.M.; Sanchez, J.; Vestal, M.L.; Hochstrasser, D. F. Matrix-assisted laser desorption/ ionization-tandem mass spectrometry with high resolution and sensitivity for identification and characterization of proteins. Proteomics 2002, 2(7), 868-876

45. Polce, M. J.; Cordero, M. M.; Wesdemiotis, C.; Bott, P. A. A New Trisector Tandem Mass Spectrometer for Neutralization-Reionization Studies. Int. J. Mass Spectrom. Ion Processes 1992, 113, 35-58.

46. McLuckey, S. A.; Van Berkel, G. J.; Goeringer, D. E.; Glish, G. L. Ion Trap Mass Spectrometry of Externally Generated Ions. Anal. Chem. 1994, 66, 689A-696A.

48. Baer, T.; Hase, W. L. Unimolecular Reaction Dynamics; Oxford University Press: Oxford, 1996.
49. El Aribi, H.; Orlova, G.; Rodriquez, C.F.; Almeida, D. R. P.; Hopkinson, A. C.; Siu, K. W. M. Fragmentation Mechanisms of Product Ions from Protonated Tripeptides. J. Phys. Chem. B 2004, 108(48), 18743-18749.

50. Pingitore, F.; Wesdemiotis, C.; Paizs, B. Competitive Loss of Small Molecules in Peptides. Proceedings of the 52nd ASMS Conference on Mass Spectrometry and Allied Topics; Nashville, TN, May, 2004.

51. Lifshitz, C. Kinetic shifts. Eur. I. Mass Spectrom. 2002, 8, 85-98.

52. Rodriquez, C. F.; Cunje, A.; Shoeib, T.; Chu, I. K.; Hopkinson, A.C.; Siu, K. W. M. Proton migration and tautomerism in protonated triglycine, J. Am. Chem. Soc. 2001, 123, 3006-3012.

53. Paizs, B.; Suhai, S. Combined quantum chemical and RRKM modeling of the main fragmentation pathways of GGG. I. Cis-trans isomerization around protonated amide bonds. Rapid Commun. Mass Spectrom. 2001, 15, 2307-2323.

54. Polfer, N. C.; Oomens, J.; Suhai, S.; Paizs, B. Spectroscopic and Theoretical Evidence for Oxazolone Ring Formation in Collision-Induced Dissociation of Peptides. J. Am. Chem. Soc. 2005, 127, 17154-17155.

55. Harrison, A. G. The gas-phase basicities and proton affinities of amino acids and peptides. Mass Spectrom. Rev. 1997, 116, 201-217.

56. Bleiholder, C.; Suhai, S.; Paizs, B. Revising the Proton Affinity Scale of the Naturally Occurring $\alpha$-Amino Acids. J. Am. Soc. Mass Spectrom. 2006,17, 1275-1281.

57. Lifshitz, C. Some recent aspects of unimolecular gas phase ion chemistry. Chem. Soc. Rev. 2001, 30, 186-192.

58. Csonka, I. P.; Paizs, B.; Lendvay, G.; Suhai, S. Proton mobility in protonated peptides: A joint molecular orbital and RRKM study. Rapid Commun. Mass Spectrom. 2000, 14, 417-431.

59. Paizs, B.; Csonka, I. P.; Lendvay, G.; Suhai, S. Proton mobility in protonated glycylglycine and N-formylglycylglycinamide: A combined quantum chemical and RKKM study. Rapid Commun. Mass Spectrom. 2001, 15, 637-650.

60. Laerdahl, J. K.; Uggerud, E. Gas phase nucleophilic substitution. Int. J. Mass Spectrom. 2002, 214, 277-314.

61. Gritsenko, O. V.; Ensing, B.; Schipper, P. R. T.; Baerends, E. J. Comparison of the Accurate Kohn-Sham Solution with the Generalized Gradient Approximations (GGAs) for the SN2 Reaction F- $+\mathrm{CH} 3 \mathrm{~F}-/>$ FCH3 + F-: A Qualitative Rule To Predict Success or Failure of GGAs. J. Phys. Chem. A 2000, 104, 8558-8565.

62. Tu, Y.-P.; Harrison, A. G. Fragmentation of Protonated Amides Through Intermediate Ion-Neutral Complexes: Neighboring Group Participation. J. Am. Soc. Mass Spectrom. 1998, 9(5), 454-462.

63. McLafferty, F. W.; Turecek, F. Interpretation of Mass Spectra, 4th ed University Science Books: Mill Valley, CA, 1993, pp. 51-84. 